\title{
Development of Rapid Diagnostic Reagents for Respiratory Tract Infections in Children
}

Kei Numazaki

Division of International Infectious Diseases, Graduate School and Departments of Pediatrics, University Hospital, International University of Health and Welfare.

Eur J Basic Med Sci 2015;5(4): 51-60

Received: 13-04-2016

Accepted: 27-05-2016

Correspondence (Yazıșma Adresi):

Kei Numazaki, MD, PhD

Professor \& Chair

Division of International Infectious Diseases, Graduate School Departments of Pediatrics and Infection Control, University Hospital International University of Health and Welfare 537-3 Iguchi, Nasushiobara, Tochigi, 329-2763 Japan

TEL. +81-287-39-3060

$F A X .+81-287-39-3001$

E-mail: numazaki@iuhw.ac.jp

\begin{abstract}
Rapid diagnosis of respiratory tract infections is important not only from the standpoint of clinical diagnosis but also infection control. The purpose of the present study is to investigate the possibility of diagnosing with the immunochromatography for pathogens of respiratory tract. A prospective, populationbased study covering the total population less than 15 years of age in Tochigi, Japan, during the period of December 2010 to March 2013. Nasopharyngeal swabs were collected from 200 children with respiratory tract infections. RT$P C R$ analysis was used as the reference assay. The correlation of the results between obtained by the diagnostic reagents and RT-PCR assays was investigated. Pathogens were identified in a total of 64 (32.0\%) out of 200 patients by RT-PCR as follows: respiratory syncytial (RS) virus, 29; M. pneumoniae, 17; metapneumovirus, 7; adenovirus, 5; influenza $A$ virus, 3; and influenza $B$ virus, 3. More than 100 copies/ $\mu$ l of Mycoplasma pneumoniae was obtained. Minimum detection sensitivity of the immuno-chromatography in the clinical material was the $4 \times 10^{1}$ copies/micro-liter. The correlation of the results between obtained by the diagnostic reagent for measles and RT-PCR was the positive match rate of $45.5 \%$ and negative match rate is $100 \%$. From 79.0 to $100 \%$ of $R T-P C R$ positive samples more than $4 \times 10^{1}$ copies/micro-liter was detected. The importance of $M$. pneumoniae and RS virus in the etiology of respiratory tract infections in was confirmed. Immuno-chromatography can be applied as a simple rapid diagnostic method from the beginning of the disease in general clinical practice.
\end{abstract}

Key Words: Rapid diagnosis, immuno-chromatography, $R T-P C R$, respiratory tract infection, virus.

Çocuklarda Solunum Yolu Enfeksiyonları Için Hızlı Tanı Reaktiflerinin Gelişimi

\section{ÖZET}

Solunum yolu enfeksiyonlarının hızlı tanısı sadece klinik tanı açısından değil, aynı zamanda enfeksiyon kontrolü açısındanda önemlidir. Bu çalıșmanın amacı, solunum yolu patojenleri için imünokromagrofi ile teșhis olasılığını araștırmaktır. Mart 2013 ile Aralık 2010 dönemindeki Japonya'nın Tochigi bölgesindeki yașları 15 'den daha küçük olan, toplam nüfusu kapsayan toplum temelli, prospektif 
bir çalıșmadır. Solunum yolu enfeksiyonu olan 200 çocuktan nazofarenks sürüntü alındı. Referans yöntem olarak RT-PCR analizi kullanıldı. Tanı reaktifleri ve RT-PCR ölçümleri ile elde edilen sonuçlar arasındaki korelasyonu araștırıldı. Patojenler, RT-PCR ile 200 hastanın toplam 64 (\%32.0)' ünde așağıdaki gibi tespit edilmiștir: Solunum sinsisyal (RS) virüsü, 29; M. pneumoniae 17; metapnömovirüsü, 7; adenovirüs, 5; influenza $A$ virüs, 3; ve influenza $B$ virüsü, 3. Mycoplasma pneumoniae 100 kopya/ $\mu$ l'den daha fazla elde edildi. Klinik materyalde imünokromagrafinin minimum tanısal duyarlılığı 4 × $10^{1}$ kopya/mikrolitre idi. Kızamık için tanı ayıracı ve RT-PCR ile elde edilen sonuçlar arasındaki korelasyonun pozitif eșleșme oranı \% 45,5 ve negatif eșleme oranı\% 100 idi. RT-PCR'ın \% 79.0 - 100'ünde pozitif örnekler $4 \times 10^{1}$ kopya / mikrolitreden daha fazla tespit edildi. Solunum yolu enfeksiyonlarının etiyolojisinde, M. pneumoniae ve RS virüsü önemi teyit edilmiștir. Immüno kromatografi genel klinik uygulamada hastalık başlangıcından itibaren basit, hızlı bir tanı yöntemi olarak uygulanabilir.

Anahtar Kelimeler: Hızlı tanı; immuno-kromatografi; RT-PCR; solunum yolu enfeksiyonu; virüs.

\section{INTRODUCTION}

Establishment of rapid diagnosis of respiratory viral and mycoplasmal infections in children is important not only from the standpoint of clinical diagnosis but also infection control $(1,2)$. Since atypical cases of pediatric respiratory infections are not uncommon, diagnosis based on laboratory testing is required $(3,4)$. Laboratory diagnosis by serum IgM antibody-detection, reverse Transcription (RT)-PCR assay, and viral isolation are now established for the confirmation of the diagnosis of respiratory infections. Because of high sensitivity and specificity, these methods are the most reliable for laboratory diagnosis of viral and mycoplasmal infections $(5,6)$. However, although they are effective for epidemiological investigation, they are not suitable for use in daily clinical practice (7). Not from the importance of rapid diagnosis, the experimental laboratory diagnosis of respiratory infections has been reemphasized to establish the daily application in general clinics.

There are several different assays to get the diagnosis of respiratory tract infections such as influenza. The gold standard for define diagnosis of influenza is virus isolation with tissue culture which usually takes 2 to14 days after inoculation of clinical specimens. Detection of virusinfected cells in nasopharyngeal secretions by direct or indirect immunofluorescent staining is widely used but needs techniques of collection samples. It still requires at least 2 hours getting the results. RT-PCR remains the method of choice for clinical diagnosis of special influenza viruses in respiratory specimens and for differentiating it from seasonal viruses (1).

Differentiation of influenza virus from other respiratory viruses is of prime importance because influenza is associated with higher rates of morbidity and mortality, is potentially preventable by vaccination, and can now be treated with specific antiviral agents (8). Since the diagnosis of influenza can be difficult when based solely on clinical symptoms, rapid diagnosis of influenza permits the initiation of antiviral therapy within a beneficial time frame, can result in discontinuation of inappropriate antibiotics, and prompts infection control measures to reduce spread in healthcare settings (9).

The immuno-chromatographic method, including lateral flow-based rapid diagnosis reagents, is widely used for daily point of-care testing in almost all Japanese clinics (10). These reagents have been developed and marketed for the diagnosis of respiratory infectious disease such as influenza. The rapid influenza diagnostic tests based on immunochromatographic lateral flow-based rapid diagnosis reagents flow, is currently the best choice for screening samples for the diagnosis of influenza virus due to its rapid detection ability, simple operation and low cost. This method is unable to further classify influenza A virus subtypes and is not as sensitive as RT-PCR. It can provide a rapid diagnosis of influenza $A$ or $B$ infection to aid clinical management in half an hour.

We already reported about the fundamental results of rapid diagnostic reagent for measles $(11,12)$. To detect the measles virus in clinical samples, a reagent has to react with each of wild 23 genotypes (13). In a previous study, more than 100TCID50 of measles virus was detected from nasopharyngeal swabs $(11,12)$. The purpose of the present study is to investigate the possibility of diagnosing with rapid diagnostic reagents for viral and mycoplasmal antigens of pediatric respiratory tracts.

\section{MATERIAL AND METHOD}

\section{Clinical specimens}

We conducted a prospective, population-based study covering the total population less than 15 years of age in Nasu-shiobara, Tochigi, Japan, during the period of December 2010 to March 2013 (Figure 1, Figure 2). 
During the time of April to June 2011 the investigations were interrupted due to the big earthquake which attacked east part of Japan including Tochigi Prefecture. Nasopharyngeal swabs were collected from 200 children with respiratory-tract infections. Results are expressed as the equivalent of copies per micro-liter according to titration of control RNA. The correlation of the results $w$ as investigated.

Specimen collection was performed by the authors' responsibilities under the agreement based on ethical guidelines on clinical research (issued by the Ministry of Education and Science and the Ministry of Health, Welfare and Labor of Japan) and the Helsinki Declaration (World Medical Association). All study procedures were approved by the Research Ethics Committee of International University of Health and Welfare, Tochigi, Japan (Reference No. YM 10-08).

\section{The lateral flow-based immuno-chromatography}

In order to select the target protein for the lateral flowbased rapid diagnostic kit, 25 reagents were prepared with previously-developed antibodies for measles $\mathrm{H}, \mathrm{F}, \mathrm{M}$ and $\mathrm{N}$ proteins, and the detection limits of them were examined using cultured virus of Edmonston strain $(14,15)$. $\mathrm{B} 4$ antibody to $\mathrm{N}$ protein exhibited 10 times higher sensitivity than the other antibodies (16). Rated measurement sensitivity using cultured measles virus, about reagent system already includes a wild stock.

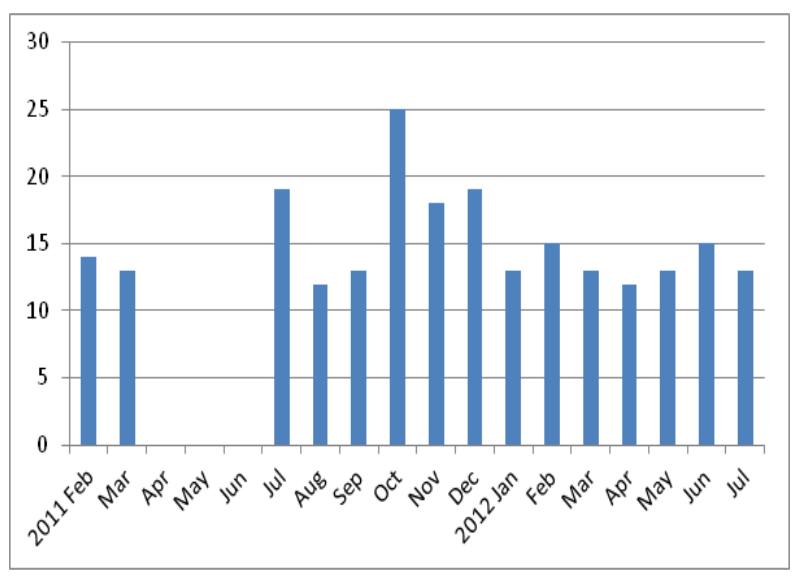

Figure 1. Monthly Distribution of Patients (Monthly Cases, n=200; April to June 2011 were interrupted by earthquake).
Evaluation of the diagnostic reagent using clinical samples

During the time of March 2008 to July 2010 clinical samples were obtained from the 46 patients ( 0 to 38 years of age; average 8.1 years, 25 males, 21 female) with suspected measles infection at 14 medical facilities in the area of Tokyo, Chiba, Osaka and Hokkaido of Japan. In the collaboration facilities, nasopharyngeal specimens of patients were collected and diagnosed with the test kit. Patients suspected measles clinical findings more than throat swab taken, evaluation of rapid tests kits. The residual samples for the diagnostic reagent were analyzed with RT-PCR in the laboratory.

We examined the correlation between the diagnostic reagent and RT-PCR $(17,18)$, and the clinical symptoms in non-measles patients. Detection sensitivity compared with RT-PCR method using the clinical material collected from this time at 14 facilities.

Specimen collection was done by the physicians' responsibilities under the agreement based on ethical guidelines on clinical research (issued by the Ministry of Education and Science and the Ministry of Health, Welfare and Labor of Japan) and the Helsinki Declaration (World Medical Association).

\section{Quantitative real-time RT-PCR assay}

Real-time RT-PCR analysis was carried out using primers and protocols previously described $(17,18)$. For the Taq

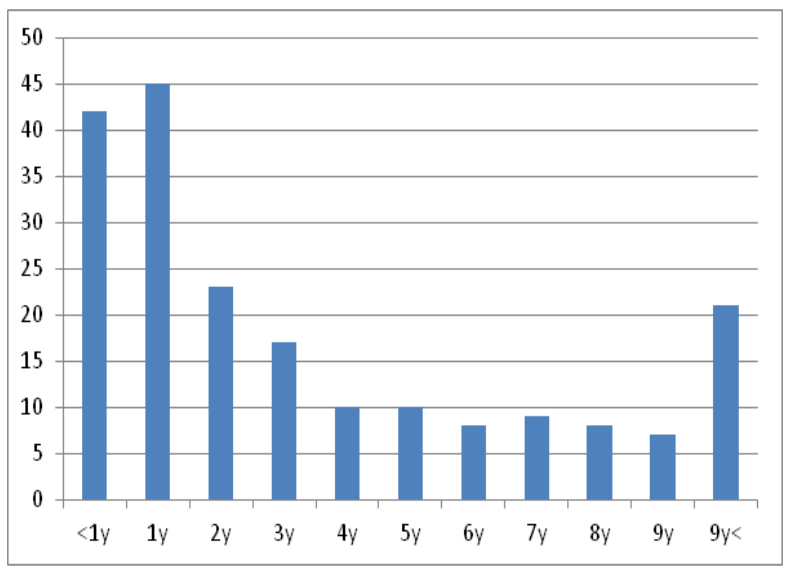

Figure 2. Age Distribution of Patients (n=200). 
$\times 10^{1}$ Copies/ $\mu \mathrm{L}$

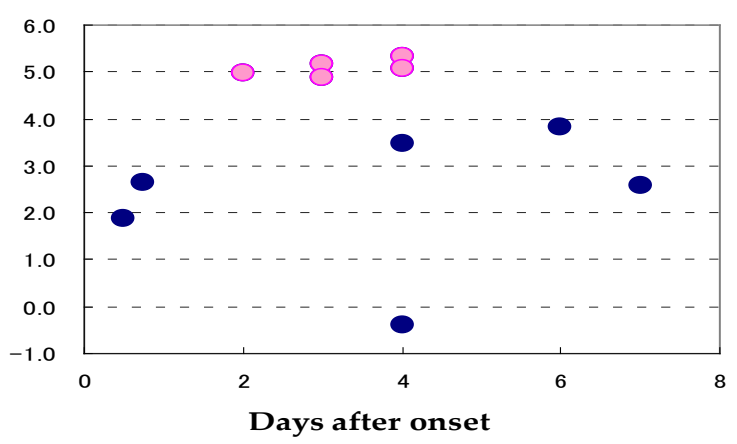

Results of the Diagnostic Reagent

Positive

- Negative

Figure 3. Time Distribution of Positive Specimens by RT-PCR assay.

Man PCR method, we used the N3 primer and probe set for measles described in a previous paper (12). One-step RT-PCR reactions were performed in duplicate in an eight well optical micro tube (Applied Biosystems, Carlsbad, CA). A One Step Prime Script RT-PCR Kit (Takara-Bio, Otsu, Japan) was used for the PCR reagent. Briefly, a 25 $\mu \mathrm{l}$ reaction was set up containing $5 \mu \mathrm{l}$ of template RNA, $12.5 \mu \mathrm{l}$ of 2 X RT-PCR master mix, $1 \mu \mathrm{l}$ of 25 X RT-PCR enzyme mix, $0.5 \mu \mathrm{l}$ of Probe $(20 \mu \mathrm{M}), 0.5 \mu \mathrm{l}$ of each of the primers $(40 \mu \mathrm{M})$ and $5 \mu$ l of RNase-free water. A $5 \mathrm{~mL}$ RNA sample or control RNA sample was analyzed in $25 \mathrm{~mL}$ of reaction mixture. Thermal cycling conditions consisted of $45^{\circ} \mathrm{C}$ for $10 \mathrm{~min}$, followed by $95^{\circ} \mathrm{C}$ for $10 \mathrm{~min}$ and then 40 cycles of $95^{\circ} \mathrm{C}$ for $15 \mathrm{~s}, 60^{\circ} \mathrm{C}$ for $45 \mathrm{~s}$. Real-time assays were performed with the ABI PRISM 7500 sequence detection system (Applied Biosystems). Threshold cycle (Ct) values were calculated for each reaction. Samples were considered positive only if $\mathrm{Ct}$ values were less than $\mathbf{4 0}$ for both replicates. Results are expressed as the equivalent of copies $\mathrm{mL}$, according to titration of control RNA. Viral RNA and non-viral RNA were used as positive and negative controls, respectively while RNase free water was used as blank control.

Nucleic acid extraction, primer design, and PCR conditions for other viruses and Mycoplasma were carried out as described previously $(19,20,21)$. Duplicate aliquots of each specimen underwent automated NucliSens total nucleic acid extraction according to the manufacturer's instruc-

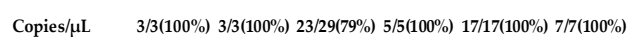

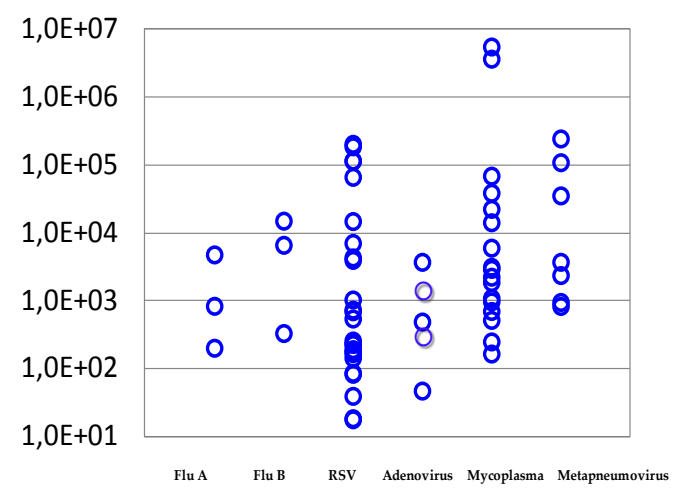

Figure 4. Number of Copies in Clinical Specimens more than 40 copies/micro-liter, Detection Limit of Immunochromatography $b y \square R T-P C R$.

tions $(22,23,24)$. RNA extracts either were immediately tested by RT-PCR or were stored at $-70^{\circ} \mathrm{C}$ in nuclease-free water containing RNase inhibitor. Oligonucleotide primers for respiratory syncytial (RS) virus, M. pneumoniae, metapneumovirus, adenovirus, influenza A virus and influenza B virus were designed to achieve standardized annealing temperatures $(20,22)$. Primers for human B-actin mRNA were used to test for adequacy of the specimen, extraction, and RT-PCR procedure. The positive-strand primer of each set was labeled at the $5^{\prime}$ end with the fluorescent dye 6-carboxyfluorescein to enable automated GeneScan software analysis (Applied Biosystems). RT-PCR assays for each virus were also individually performed.

\section{RESULTS}

Sensitivity and specificity of the lateral flow-based immuno-chromatography diagnostic reagent system

In 46 clinical specimens for measles 5 were positive by the diagnostic reagent and 11 were positive by RT-PCR assay. These 5 reagent-positive specimens were also positive by RT-PCR assay (Figure 3). Minimum detection sensitivity of the reagent system in the clinical material was the $1 \times 104$ copies/micro-liter. Specimens were positive in onset later in 2-4 clinical days of measles, 7 samples in the RT-PCR assay. The correlation of the results between 


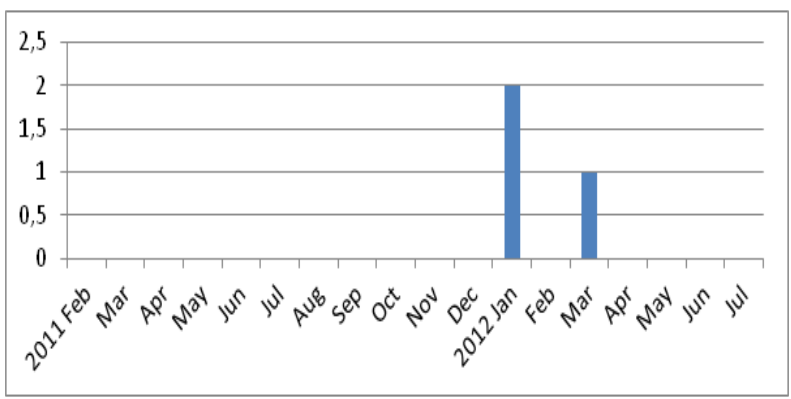

Figure $5 a$ Cases of Influenza A ( $n=3)$.

Figure 5a-f. Time distribution of Etiologic Agents by $R T-P C R$ assay.

obtained by the diagnostic reagent for measles and RTPCR was the positive results that match rate of $45.5 \%$. Negative in the entire RT-PCR negative example of 35 samples was a negative match rate is $85.4 \%$. From 79.0 to $100 \%$ of RT-PCR positive samples of other viruses and Mycoplasma copies more than $4 \times 10^{1}$ copies/micro-liter of positive results were obtained (Figure 4). More than $4 \times 10^{1}$ copies/micro-liter were detected from $3 / 3(100 \%)$ of Influenza A, 3/3(100\%) of Influenza B, 23/29(79\%) of RS virus, $5 / 5(100 \%)$ of Adenovirus, $17 / 17(100 \%)$ of $M$. pneumoniae and $7 / 7(100 \%)$ of Metapneumovirus samples positive by RT-PCR assay. We detected 100 copies in the sample/ $\mu \mathrm{l}$ or more antigens of $M$. pneumoniae and metapneumovirus which were difficult for detection by the conventional method.

Time distribution of positive specimens by the lateral flow-based immuno-chromatography diagnostic reagent system and by RT-PCR assay

We also examined the correlation between the diagnostic reagent and RT-PCR assay, and the symptoms in non-measles patients. In what had been diagnosed with measles in clinical findings so far Koplik's spots, judged measles diagnosis differential diagnosis difficult clinical symptoms alone was RT-PCR negative results. Although non-measles patients showed measles-like symptoms, the diagnostic reagent did not exhibit false-positive. We confirmed that the diagnostic reagent could detect measles in clinical samples. The diagnostic reagent detected $71 \%(5 / 7)$ of measles cases at 2-4 day after onset of fever (Figure 3).

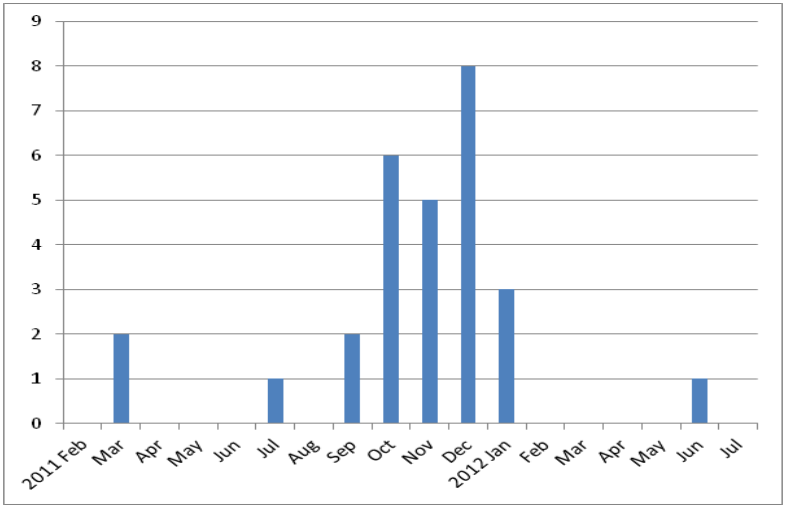

Figure $5 b$ Cases of $R S$ virus ( $n=29)$.

Figure 5a-f. Time distribution of Etiologic Agents by $R T-P C R$ assay.

\section{Specific etiology}

Specific infectious agents were identified in a total of 64 (32.0\%) out of 200 patients with respiratory tract infections by RT-PCR assay as follows: respiratory syncytial (RS) virus, 29; M. pneumoniae, 17; metapneumovirus, 7; adenovirus, 5; influenza A virus, 3; and influenza B virus, 3. Although RS and Influenza-positive samples were mainly obtained in winter time, several M. pneumoniae-positive samples were obtained in summer time (Figure 5a-f).

\section{DISCUSSION}

Acute respiratory infections, mostly caused by viruses and $M$. pneumoniae, are the most common illness experienced by healthy children worldwide as a major impact on health (25). Upper respiratory tract infections such as acute pharyngitis are prevalent in infants and children and continue to be common in young adults. Infants and children may have 3-8 episodes of common cold annually which lead to complications such as acute otitis media, asthma exacerbation, and lower respiratory tract infections. Although pneumonia, bronchitis, and bronchiolitis occur much less frequently, they cause higher morbidity associated with significant impact and greater healthcare costs. Approximately one third of infants develop lower respiratory tract infections in the first year of life. The incidence decreases to $5 \%-10 \%$ during school year, and $5 \%$ during ordinary young adult years. 


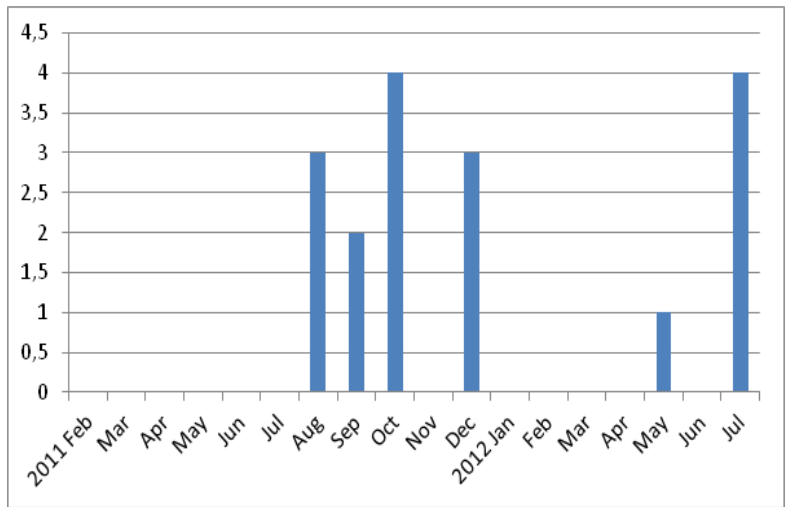

Figure 5c Cases of Mycoplasma pneumoniae ( $n=17)$.

Figure 5a-f. Time distribution of Etiologic Agents by RT-PCR assay.

Influenza A and B, RS virus, parainfluenza virus, adenovirus, rhinovirus, human metapneumovirus, and coronaviruses are common viruses of respiratory tract $(26,27,28)$. Clinical significance of recently discovered new viruses such as human bocavirus has yet to be elucidated $(29,30)$. Clinical manifestations of viral infections of respiratory tract overlap among those caused by various other viruses. Effective antiviral treatment for respiratory virus infections is only available for influenza (26). Rapid diagnosis of respiratory viral infections is an integral part of health care. Accurate diagnosis of specific respiratory virus infection can affect patient management and help prevent secondary spread of the infection. Rapid viral diagnosis can result in discontinuation of unnecessary antibiotics and antiviral agents, reduction of costs related to reduction of unnecessary medical investigations, and shortened hospitalization (1).

A variety of microbiological assays have been applied to identify etiological agents from patients with respiratory tract infections. Although methods to determine etiological agents such as Gram's stain, isolation by tissue culture from clinical specimens and serum antibody detection have been widely utilized, due to the absence of a widely applicable international reference standard, none is indisputably predictive of the true cause of upper respiratory tract infections. Serological assays, antigen detection, RT-PCR study and isolation of the organism are used to determine viral etiology. Our results confirm many features of the etiology of lower respiratory tract infections that have been demonstrated in previous stud-

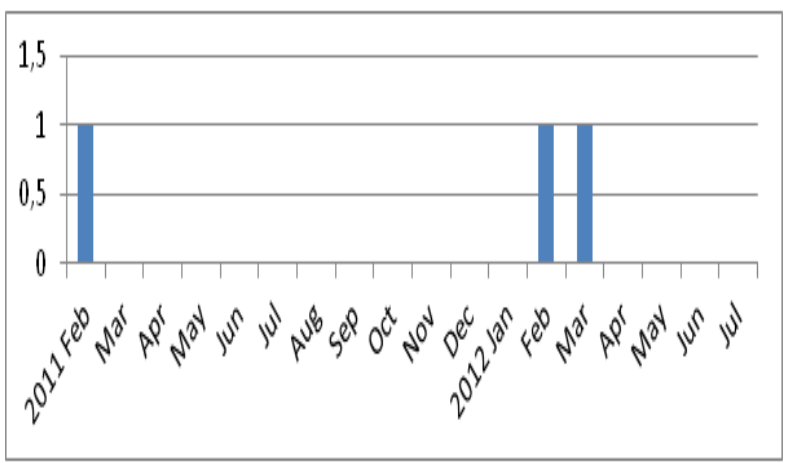

Figure $5 d$ Cases of Influenza B ( $n=3)$.

Figure 5a-f. Time distribution of Etiologic Agents by RT-PCR assay.

ies, in particular the high proportion of patients with mycoplasmal and viral infection $(31,32)$. Although more information is needed about outpatients who are estimated to compromise more than half of the pediatric patients with community-acquired pneumonia or bronchitis, most etiologic studies have been conducted in hospitals in industrialized countries or in clinics for outpatients in developing countries.

The significance of mixed or poly-microbial etiology hasaincreasingly been appreciated in the literature, particularly in studies that apply new, sensitive diagnostic methods to identify infection with Mycoplasma, Chlamydia and viruses (34). S. pneumoniae and M. pneumoniae were the major etiological causes of community-acquired pneumonia in children in previous studies, together accounting for up to $60 \%$ of cases (35). It is suggested that $M$. pneumoniae may predispose to secondary bacterial or viral infection.

The etiological profile among our hospitalized children accords well with the combined information from previous studies of community-acquired pneumonia and bronchitis in essentially unselected adult patients admitted to hospital. The divergent results are partly related to endemic and epidemic causes and partly to the microbiological methods. Unlike most studies of lower respiratory tract infections, the etiology remained unidentified in a relatively small proportion of the total cases in the present study. The hospitalization rate among these patients was not higher suggesting that most of the unidentified organisms caused more severe disease. 


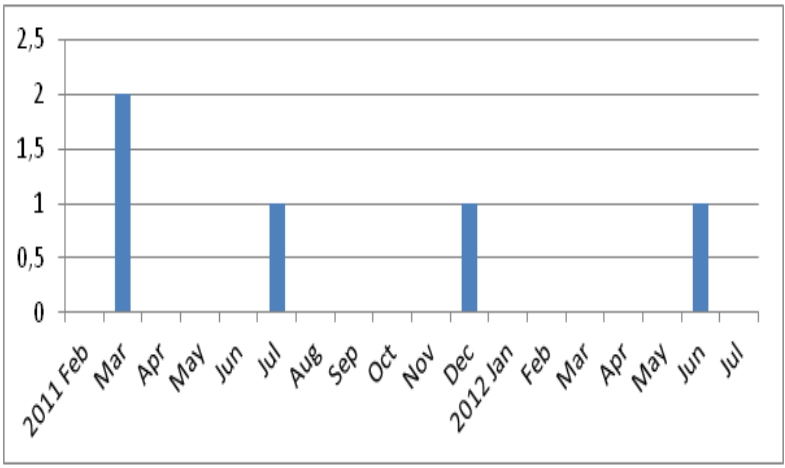

Figure 5e Cases of Adenovirus ( $n=5)$.

Figure 5a-f. Time distribution of Etiologic Agents by RT-PCR assay.

RS virus sometimes cause pneumonia in young infants, but more typically cause bronchitis or bronchiolitis. $M$. pneumoniae infections are common in school-aged children and are estimated to cause half of the cases or more $(3,36)$. The etiological findings for younger adult patients resembled those for the older children enrolled in our present study; the proportions of Mycoplasma and RS virus infections were, however, higher especially among children less than 5 years of age.

To investigate the etiology of $M$. pneumoniae infections we conducted a prospective study covering the total pediatric population in Hokkaido, Japan $(31,32)$. Paired sera for serologic assays were available for more than half of the cases $(n=921 ; 398$ as pneumonia and 523 as bronchitis). The nasopharyngeal swabs were also collected for isolation and PCR study. M. pneumoniae was identified in 174 (43.7\%) out of 398 patients with pneumonia and was identified in $78(14.9 \%)$ out of $523(86.2 \%)$ patients with bronchitis. Mycoplasmal infections were seen even in patients less than 5 years of age. Although two genetically distinct types of $M$. pneumoniae are known, variants of each also exist. Real-time PCR high-resolution melt genotyping assay was applied to identify clinical variants which may provide greater insight into the genetic distribution of M. pneumoniae strains (33). Generation of antigenic variation by DNA recombination may occur in clinical isolates (32).

For most respiratory viruses, the delay in transport of clinical specimens to the diagnostic laboratory is usu-

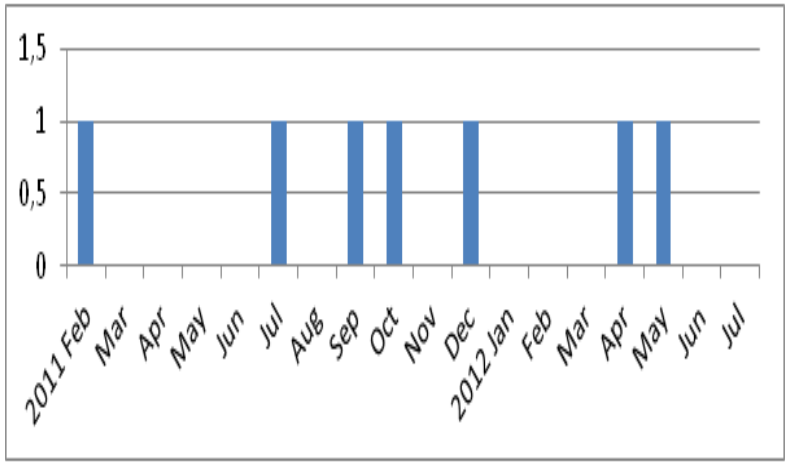

Figure $5 f$ Cases of Metapneumovirus ( $n=7$ ).

Figure 5a-f. Time distribution of Etiologic Agents by RT-PCR assay.

ally the major factor in both slowness of the process and a failure to make an appropriate clinical diagnosis. It should be possible to diagnose virus infections rapidly by electron microscopy and culture. It is necessary to make the diagnosis of respiratory tract virus infection more reliable and speedier. Molecular probes, and gene amplification, overcome these problems and have become routine standard technologies in the diagnostic setting (37).

Molecular biological assays have the advantages over conventional tissue culture methods of greater speed, specificity and sensitivity (1). They may be the only applicable techniques as many micro-organisms are fastidious and cannot be easily grown for phenotypic analysis in the ordinary laboratory. Apart from detection, molecular methods are now becoming standard for establishing quantitative estimates, particularly with regard to monitoring treatment, and resistance to therapy.

Detection of mRNA by RT-PCR has been successfully applied to the differential diagnosis of active viral infections. In RT-PCR, amplification (as detected by an increase in fluorescence) and analysis occur simultaneously. RT-PCR is well suited for quantitative analysis, but currently available commercially kits for detection of respiratory virus nucleic acids have only qualitative claims. RT-PCR instruments are limited in the number of emission channels available for multiplexing. Commercially available multiplex RT-PCR kits are generally limited to the detection of four or fewer nucleic acid targets (38). One of the targets is usually an internal control. FDA-cleared 
RT-PCR assays are currently available for the detection of influenza A (including subtypes) and influenza B viruses, RSV, parainfluenza viruses 1,2 , and 3 , and human metapneumovirus. Studies have demonstrated that molecular amplifications methods including real-time RT-PCR provide the most sensitive detection of respiratory viruses $(17,18)$.

Diagnostic system used in the clinical evaluation of a rapid diagnostic reagent by immuno-chromatography has helped real rapid diagnosis in infections associated with such as influenza virus, RS virus, adenovirus, and Streptococcus from the superior speed and simplicity $(8,9,10)$. Considering the time, difference in specificity and sensitivity comparisons with RT-PCR assay for detection of virus measles genome, immuno-chromatography was usually utilized from the beginning of the disease in general medical clinics (39).

Compared with RT-PCR assay, the sensitivity of the lateral flow-based immuno-chromatography rapid diagnostic reagent system was also much higher than that of other commercially available kits $(11,12)$. The high sensitivity of the diagnostic test kit was confirmed by influenza A specimens that were confirmed by RT-PCR. As compared to influenza virus low titer of other viruses exist in the nasopharynx depending on time of specimen collection, the diagnostic reagent lower sensitivity than that of the RT-PCR assay. In this study high viral load time (2 to 4 clinical days after onset) in specimens has been achieved with regard to detection of measles virus. A further sensitivity is required including the purification of monoclonal antibody to the general practical level.

Considering the time, difference in specificity and sensitivity comparisons with RT-PCR assay, immuno-chromatography can be usually utilized from the beginning of the infectious diseases in general medical clinics. From the results of this study it can be applied as simple rapid diagnostic methods for pediatric respiratory infections in general clinical practice.

During the past several years, improvements are noticed in respiratory virus diagnostics, from novel specimen collection instruments to highly sensitive and multiplexed nucleic acid amplification tests. With the expanding list of antigen and molecular-based tests, it is now possible for laboratories to offer comprehensive testing for respiratory viruses without even performing virus isolation. Current diagnostic options will include antigen, molecular, and culture-based methods. It is important that diag- nostic virologists and clinicians understand these characteristics and limitations.

In conclusion, the proportion of patients with Mycoplasma infections did not increase and that of patients with RS and influenza A viruses decreased with age, but for each age group, the etiological profile was completely different between inpatients and outpatients. Mycoplasma infections were seen even in patients less than 5 years, and RS and influenza A virus infections in patients more than 5 years of age. The results of our study confirm the importance of M. pneumoniae and RS virus in the etiology of community-acquired respiratory infections in Japanese children.

Further study overlapping on clinical specimen types, collection methods, collecting time and times of collection with diagnostic kits currently available for adenovirus, Streptococcus and influenza virus will improve diagnostic value (7). Also rise of serum IgM antibody is a biological reaction due to infections (40), the sensitivity and specificity of difference of the lateral flow-based immunochromatography and had been estimated in this study.

\section{Conflict of interest}

No commercial relationship or potential conflict of interest related to the submission of this manuscript.

\section{Acknowledgments}

The author expresses thanks to Yukio Hamaguchi and Takeshi Imoarai, Sysmex Corporation, Kobe, Japan, for their valuable technical assistance.

\section{REFERENCES}

1. Myint S. Recent advances in the rapid diagnosis of respiratory tract infection. Br. Med. Bull. 2002; 61: 97-114.

2. Mahony JB. Detection of respiratory viruses by molecular methods. Clin. Microbiol. Rev. 2008; 21: 716-47.

3. Jartti $T$, Jartti L, Peltola V, Waris M, Ruuskanen $O$. Identification of respiratory viruses in asymptomatic subjects: asymptomatic respiratory viral infections. Pediatr. Infect. Dis. J. 2008; 27: 1103-7.

4. van der Zalm MM, van Ewijk BE, Wilbrink B, Uiterwaal CSPM, Wolfs TFW, van der Ent CK. Respiratory pathogens 
in children with and without respiratory symptoms. J. Pediatr. 2009; 154: 396-400.

5. Winther B, Alper CM, Mandel EM, Doyle WJ, Hendley JO. Temporal relationships between colds, upper respiratory viruses detected by polymerase chain reaction, and otitis media in young children followed through a typical cold season. Pediatrics 2007; 119: 1069-75.

6. Liu F-C, Chen P-Y, Huang F-L, Tsai C-R, Lee C-Y, Wang L-C. Rapid diagnosis of Mycoplasma pneumoniae infection in children by polymerase chain reaction. J. Microbiol. Immunol. Infect. 2007; 40: 507-12.

7. Mubarak HS, Van De Bildt MW, Mustafa OA, Vos HW, Mukhtar MM, Groen J, El Hassan AM, Niesters HG, Ibrahim SA, Zijlstra EE, Wild TF, Osterhaus AD, De Swart RL. Serological and virological characterization of clinically diagnosed cases of measles in suburban Khartoum. J. Clin. Microbiol. 2000; 38: 987-91.

8. Hurta AC, Alexanderc R, Hibbert J, Deeda N, Barra IG. Performance of six influenza rapid tests in detecting human influenza in clinical specimens. J. Clin. Virol. 2007; 39: $132-5$.

9. Nerbrand C, Jasir A, Schalén C. Are current rapid detection tests for Group A streptococci sensitive enough? Evaluation of 2 commercial kits. Scand. J. Infect. Dis. 2002; 34: 797-9.

10. Fujimoto T, Okafuji T, Okafuji T, Ito M, Nukuzuma S, Chikahira M, Nishio O. Evaluation of a bedside immunochromatographic test for detection of adenovirus in respiratory samples, by comparison to virus isolation, $P C R$ and real-time-PCR. J. Clin. Microbiol. 2004; 42: 5489-92.

11. Hasegawa T, Asaeda A, Hamaguchi Y, Numazaki K. Development of rapid diagnostic reagent for measles. Hybridoma 2009; 28: 241-9.

12. Numazaki K. A study on the clinical application of a rapid diagnostic reagent for measles. Eur. J. Gen. Med. 2012; 9: 39-44.

13. Santibanez S, Tischer A, Heider A, Siedler A, Hengel $H$. Rapid replacement of endemic measles virus genotypes. J. Med. Virol. 2002; 83: 2699-708.

14. Viola B, Viktoria G, Tatsuya S, Yaeta E, Tamas M. A set of ligation-independent in vitro translation vectors for eukaryotic protein production. BMC Biotechnol. 2008; 8: 32.

15. Graves MC. Measles virus polypeptide in infected cell studied by immune precipitation and one-dimensional peptide mapping. J. Virol. 1981; 38:224-30.

16. Sato TA, Fukuda A, Sugiura A. Characterization of major structural proteins of measles virus with monoclonal antibodies. J. Gen. Virol. 1985; 66: 1397-409.

17. Hummel KB, Lowe L, Bellini WJ, Rota PA. Development of quantitative gene-specific real-time RT-PCR assays for the detection of measles virus in clinical specimens. J. Virol.
Methods 2005; 132: 166-73.

18. Jin L, Feng Y, Parry R, Cui A, Lu Y. Real-time PCR and its application to mumps rapid diagnosis. J. Med. Virol. 2007; 70: 1761-7.

19. Dykewicz CA, National Center for Infectious Diseases, Centers for Disease Control and Prevention, Infectious Diseases Society of America, American Society for Blood and Marrow Transplantation. Guidelines for preventing opportunistic infections among hematopoietic stem cell transplant recipients: focus on community respiratory virus infections. Biol. Blood Marrow Transplant. 2001; 7: 19s-22s.

20. Winchell JM, Mitchell SL. Performing your original search, RT-PCR Detection of Mycoplasma pneumoniae by real-time PCR. Methods Mol. Biol. 2013; 943: 149-58.

21. Henrickson KJ. Advances in the laboratory diagnosis of viral respiratory disease. Ped. Inf. Dis. J. 2004; 23: s6-10.

22. Erdman $D D$, Weinberg GA, Weinberg GA, Edwards KM, Walker FJ, Anderson BC, Winter J, González M, Anderson $L J$. GeneScan reverse transcription-PCR assay for detection of six common respiratory viruses in young children hospitalized with acute respiratory illness. J. Clin. Microbiol. 2003; 41: 4298-303.

23. de-Paris F, Beck C, Machado ABMP, Paiva RM, Menezws DS, Nunes LS, Kuchenbecker R, Barth AL. Optimization of onestep duplex real-time RT-PCR for detection of influenza and respiratory syncytial virus in nasopharyngeal aspirates. J. Vitol. Methods 2012; 186: 189-92.

24. Roghmann M, Ball K, Erdman D, Lovchik J, Anderson LJ, Edelman $R$. Active surveillance for respiratory virus infections in adults who have undergone bone marrow and peripheral blood stem cell transplantation. Bone Marrow Transplantation 2003; 32: 1085-8.

25. Ison MG, Hayden FG. Viral infections in immunocompromised patients: what's new with respiratory viruses? Curr. Opin. Inf. Dis. 2002; 15: 355-67.

26. Noyola DE, Demmler GJ. Effect of rapid diagnosis on management of influenza A infections. Pediatr. Infect. Dis. J. 2000; 19: 303-7.

27. Vinh DC, Newby D, Charest H, McDonald J. Evaluation of a commercial direct fluorescent-antibody assay for human metapneumovirus in respiratory specimens. J. Clin. Microbiol. 2008; 46: 1840-1.

28. Henrickson KJ, Hall CB. Diagnostic assays for respiratory syncytial virus disease. Pediatr. Infect. Dis. J. 2007; 26: S36-40.

29. Schildgen $O$, Muller A, Allander T, Mackay IM, Sebastian Völz S, Kupfer B, Arne Simon A. Human bocavirus: passenger or pathogen in acute respiratory tract infections? Clin. Microbiol. Rev. 2008; 21: 291-304. 
30. Kesebir D, Vazquez M, Weibel C, Shapiro ED, Ferguson D, Landry ML, Kahn JS. Human bocavirus infection in young children in the United States: molecular epidemiological profile and clinical characteristics of a newly emerging respiratory virus. J. Infect. Dis. 2006; 194:1276-82.

31. Numazaki K, Chiba S, Umetsu M, Tanaka T, Yoshimura $H$, Kuniya Y, Miura J, Adachi N, Ukae S, Mori T, Ueda D, Hotsubo T, Sato T. Etiological agents of lower respiratory tract infections in Japanese children. In Vivo 2004; 18: 6772.

32. Numazaki K, Umetsu M, Adachi N. Mycoplasma pneumoniae infection and its genotypical characterization in children of Hokkaido, Japan. In Vivo 2003; 17: 421-4.

33. Schwartz SB, Mitchell SL, Thurman KA, Wolff BJ, Winchell JM. Identification of P1 variants of Mycoplasma pneumoniae by use of high-resolution melt analysis. J. Clin. Microbiol. 2009; 47: 4117-20.

34. Drummond P, Clark J, Wheeler J, Galloway A, Freeman $R$, Cant A. Community acquired pneumonia-a prospective UK study. Arch. Dis. Child. 2000; 83: 408-12.

35. Toikka P, Juven $T$, Virkki $R$, Leinonen M, Mertsola J, Ruuskanen O. Streptococcus pneumoniae and Mycoplasma pneumoniae coinfection in community acquired pneumonia. Arch. Dis. Child. 2000; 83: 413-4.

36. Atkinson TP, Waites KB. Mycoplasma pneumoniae infections in childhood. Pediatr. Infect. Dis. J. 2014; 33: 92-4.
37. Fujino M, Yoshida N, Yamaguchi S, Hosaka N, Ota Y, Notomi T, Nakayama T. A simple method for the detection of measles virus genome by loop-mediated isothermal amplification (LAMP). J. Med. Virol. 2005; 76: 406-13.

38. Kumar S, Wang L, Fan J, Kraft A, Bose ME, Tiwari S, Van Dyke M, Haigis R, Luo T, Ghosh M, Tang H, Haghnia M, Mather EL, Weisburg WG,Henrickson KJ. Detection of 11 common viral and bacterial pathogens causing communityacquired pneumonia or sepsis in asymptomatic patients by using a multiplex reverse transcription-PCR assay with manual (enzyme hybridization) or automated (electronic microarray) detection. J. Clin. Microbiol. 2008; 146:306372.

39. Kikuta $H$, Ebihara $T$, Endo R, Ishiguro N, Sakata C, Ochiai $S$, Ishiko H, Gamol R, Sato T. Development of a rapid chromatographic immunoassay for detection of Human metapneumovirus using monoclonal antibodies against nucleoprotein of hMPV. Hybridoma 2007; 26: 17-21.

40. Helfand RF, Kim DK, Gary HE Jr, Edwards GL, Bisson GP, Papania MJ, Heath JL, Schaff DL, Bellini WJ, Redd SC, Anderson LJ. Nonclassic measles infections in an immune population exposed to measles during a college bus trip. J. Med. Virol. 1998; 56: 337-41. 